\title{
Building Retrofit to Improve Energy Performance from Office to Accommodation. Case study: Tower Building, Nottingham, UK
}

\author{
Nissa Aulia Ardiani ${ }^{1}$, Suhendri ${ }^{1}$, Mochamad Donny Koerniawan ${ }^{1}$, and Rachmawan Budiarto ${ }^{2}$ \\ ${ }^{1}$ Department of Architecture, Institut Teknologi Bandung, Bandung, Indonesia \\ ${ }^{2}$ Department of Nuclear Engineering and Engineering Physics, Universitas Gadjah Mada, Yogyakarta, Indonesia
}

\begin{abstract}
Designed in Brutalism style by architect Andrew Renton, Tower Building has 17 floors for academic and lecturers' office function. As the highest point in University of Nottingham, this tower has been built for almost five decades. The aim of this project is to propose the tower retrofit from current function to accommodation purpose. Improvement in terms of function and building energy performance by applying sustainable building technologies are the objectives of the retrofit. The advanced plan of building retrofit was proposed after assessing the current building performance and determined the problems. The proposed building design was based on building performance simulation result, literature, and precedent studies. Thereafter, several technologies and design ideas were applied for further investigation, to examine how is the strategies works in the building retrofit. Integrated double skin façade with BIPV, bio composite material for internal wall, double low-e glass for external wall, as well as green lung to improve natural ventilation and create public space were proposed for the building.
\end{abstract}

\section{Introduction}

Sustainable building design can be approached in two ways, reducing energy consumption and supplying energy by renewables. In a comprehensive implementation of a sustainable building, the approaches are applied from the early phase of a project. Among the project phases, construction phase is the most energy intensive [1]. Thus, energy reduction strategies and renewable energy supply in this process are significant to minimize environmental impact.

Nevertheless, due to energy intensive characteristic of a new construction process, retrofit seems to be a prospective method. Menassa and Baer [2] have summarized some benefits from sustainable retrofit. A sustainable retrofit could span the lifetime of a building, give a better economic value for the owner, and thus decrease the lifecycle cost of the building. Retrofit also makes building more energy efficient [3]. However, Burton [4] mentions that retrofitting or refurbishment is still avoided by developers and architects due to its difficulty level. Also, a retrofit project is high risk because there are lots of uncertainties in the project [5]. Hence, the owner or developer should systematically analyze the possible results of a retrofit project, to make sure that the project is really feasible [6]. It is worth noting that the decision has a large number of possibilities and that it is a multi-objective problems [7].

Realizing the possible benefits of building retrofit, the Department of Architecture, University of Nottingham creates a case study for retrofitting the Tower Building. It is being used by the department as classrooms, offices, and laboratories and, in the case study, planned to be a postgraduate student accommodation. There is a big difference in terms of building typology and function if it is proposed to be a student accommodation. This revolution in building typology also should be sustainable. The design should resolve some of the difficulties in sustainable energy building design and in the choice of building materials and parameters. It also needs to solve realistic energy technology problems and provide clear interpolations of the significance of climatic parameters and their significance for the planning and design of building. Therefore, the designers should consider the influence of building parameters on the energy and carbon performance of buildings, understanding the need for effective zoning and internal form in the overall performance of buildings, and utilize thermal modelling and analysis. The opportunities and limitations of passive design solutions proposed should be assessed in terms of its annual energy use and $\mathrm{CO} 2$ emissions.

Considering that building retrofit in Indonesian buildings has not been intensively studied, the case study would be beneficial. There are numbers of old colonial buildings that could be retrofitted so it can be functioned for a different typology and reduce the energy consumptions.

\section{Methods}

This study consists of several stages which are: 1) Develop a building model to identify the building 
performance in the current condition as an office (before retrofit). After that, the main problems from current building were determined and anticipated by changing the function and schedule from office to accommodation. 2) Propose building design, layout, and strategies to reduce the energy consumption based on simulation result, precedent studies, and theme analysis. 3) Decide the main strategies that would be applied in the building for the retrofit to investigate the result from the simulation.

In this study, building layout, buildings materials, function, and activity were used as parameters and was simulated by using Autodesk Ecotect. Autodesk Revit and Autodesk Green Building Studio were used to make and simulate the detailed design proposal. To calculate the possibility of BIPV application in the southern façade, PVSyst software was also applied.

\subsection{Site location}

Tower building is located in East side of University Park campus in the engineering complex (see Figure 1). The building is one of the landmarks and the proposed function should improve the 'image' of the building as it can be seen from the main road of Nottingham city. Surrounded by important building features in campus, this location is suitable for the accommodation purpose. QMC hospital across the road, George Green Library, Engineering Science Learning Center, computer center, and bus stop are nearby and accessible within walk distance.

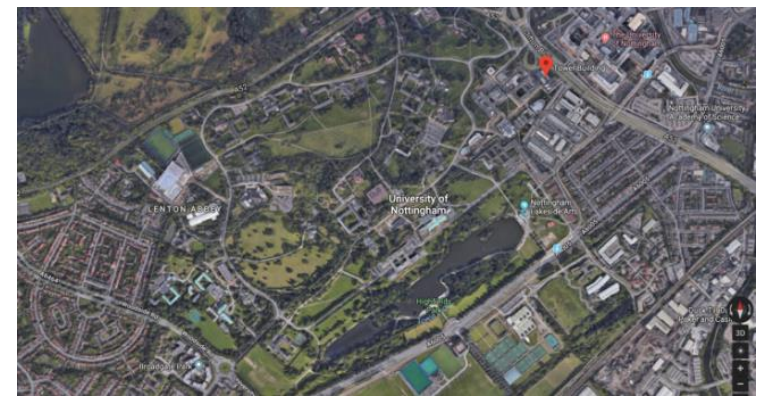

Figure 1. The location of Tower Building in the University of Nottingham from google maps.
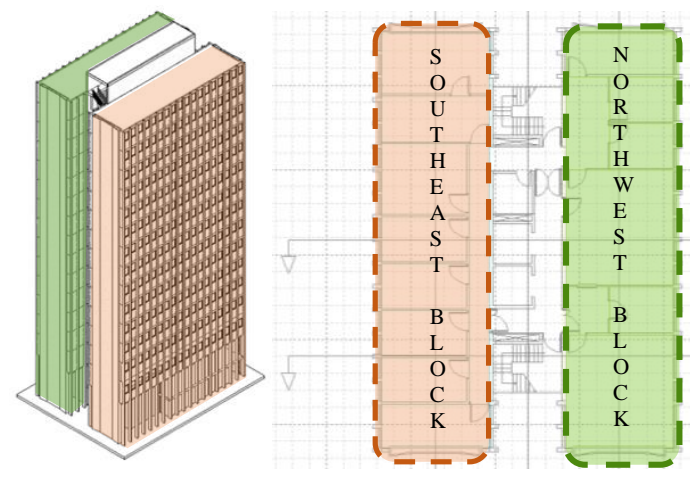

Figure 2. Axonometry (left) and the typical floor plan (right).

The Tower building consist of two masses that separated by the core for service area. The typical office and classes floor plan of the current building can be seen in the Figure 2 above. This layout was then simulated as benchmark for further study of retrofit.

\subsection{Materials}

Table 1. Material properties before retrofit.

\begin{tabular}{|c|c|c|c|}
\hline \multirow{2}{*}{ Type } & Materials & \multicolumn{2}{|c|}{ Thermal Properties } \\
\cline { 3 - 4 } & Thickness & $\begin{array}{c}\text { U-Value } \\
(\boldsymbol{m})\end{array}$ & $\left(\boldsymbol{W}^{2} \mathbf{m}^{\mathbf{K}}\right)$ \\
\hline Wall & $\begin{array}{c}\text { Plaster + Concrete } \\
\text { + Plaster }\end{array}$ & 0.248 & 1.10 \\
\hline Partition & $\begin{array}{c}\text { Framed } \\
\text { Plasterboard }\end{array}$ & 0.114 & 2.47 \\
\hline Ceiling & $\begin{array}{c}\text { Fiberfax Paper + } \\
\text { Air Gap + Plaster } \\
\text { Board }\end{array}$ & 0.3 & 2.49 \\
\hline Floor & $\begin{array}{c}\text { Concrete + Carpet } \\
\text { Underlay + Carpet }\end{array}$ & 0.41 & 0.93 \\
\hline Windows & Single Glass & 0.06 & 6.00 \\
\hline
\end{tabular}

Table 2. Material properties after retrofit.

\begin{tabular}{|c|c|c|c|}
\hline \multirow{2}{*}{ Type } & Materials & \multicolumn{2}{|c|}{ Thermal Properties } \\
\cline { 3 - 4 } & $\begin{array}{c}\text { Thickness } \\
(\boldsymbol{m})\end{array}$ & $\begin{array}{c}\boldsymbol{U} \text {-Value } \\
\left(\boldsymbol{W} / \boldsymbol{m}^{2} \mathbf{K}\right)\end{array}$ \\
\hline Wall & Concrete + Plaster & 0.248 & 1.10 \\
\hline Ceiling & $\begin{array}{c}\text { Bio Composite } \\
\text { Panel + Insulation + } \\
\text { Bio Composite } \\
\text { Panel }\end{array}$ & 0.10 & 0.46 \\
\hline $\begin{array}{c}\text { Air Gap + } \\
\text { Insulation Glass } \\
\text { Fiber Quilt + } \\
\text { Plaster Board }\end{array}$ & 0.21 & 0.50 \\
\hline Floor & $\begin{array}{c}\text { Concrete + Carpet } \\
\text { Underlay + Carpet }\end{array}$ & 0.41 & 0.93 \\
\hline Windows & $\begin{array}{c}\text { Double Low E } \\
\text { Glazed + Air Gap }\end{array}$ & 0.042 & 2.71 \\
\hline
\end{tabular}

Table 1 and 2 describe the material properties applied in both the current building and the building design retrofit proposal. Materials were chosen by considering its thermal properties as well as the sustainability.

\subsection{Simulation setting}

Daily occupancies for the office in the weekday are $100 \%$ from $8 \mathrm{am}-12 \mathrm{pm}, 50 \%$ from $12 \mathrm{pm}-1 \mathrm{pm}, 100 \%$ from $1 \mathrm{pm}-6 \mathrm{pm}, 30 \%$ from $6 \mathrm{pm}-8 \mathrm{pm}$, and the building will be emptied afterwards until the next day. On the weekend, the building is always empty. In the simulation setting in Autodesk Ecotect, internal design condition for clothing was 1.00 , humidity $60 \%$, air speed $0.5 \mathrm{~m} / \mathrm{s}$, and lighting level 300 lux. Number of occupants in one floor in accordance with room layout was 13 people with sedentary activity. Sensible gain was set to $23 \mathrm{~W} / \mathrm{m} 2$, air change rate was 0.5 , and wind sensitivity was 0.25 air changes per hour. For the HVAC system, full air conditioning was used with efficiency $95 \%$. Thermostat range was from 18-26 0C with operation hours from $8 \mathrm{am}$ to $8 \mathrm{pm}$. 
On the other hand, daily occupancies for the accommodation was different. Internal design condition and infiltration rate were same, however the schedule and the occupancy in the weekday are $50 \%$ from $8 \mathrm{am}-5 \mathrm{pm}$, $70 \%$ from $5 \mathrm{pm}-7 \mathrm{pm}, 90 \%$ from $7 \mathrm{pm}-8 \mathrm{pm}$, and the building will be $100 \%$ from $8 \mathrm{pm}-8 \mathrm{am}$ on the next day. The internal design condition for clothing, humidity, air speed, lighting level, air change rate, and wind sensitivity were identical with the office setting. Number of occupants in one floor in accordance with room layout was 8 people with resting activity, as well as sensible gain was set to $8 \mathrm{~W} / \mathrm{m} 2$. the HVAC system, full air conditioning was used with efficiency $95 \%$. Thermostat range was from $18-26{ }^{\circ} \mathrm{C}$ with operation 24 hours for every single day.

\subsection{Proposed strategies and design}

From the literature reviews and precedent studies, the technologies and ideas that would be applied in the Tower building are :

1) Integrated double skin façade with BIPV

2) Bio composite material for internal wall

3) Double low-e glass for external wall

4) Green lung to improve natural ventilation and create public space.

As can be seen in the Figure 3, the building is divided into six zones. Ground floor up to third floor are for public area (see Figure 4), while the upper floors are for private area. There are several types of accommodation depend on the occupant. For hotel or short stay, the proposed single hotel room with bathroom and sleep box can be seen in Figure 5. For master, undergraduate, and $\mathrm{PhD}$ student, there are three different choices of layout which are standard room with toilet, standard room with toilet sharing, and ensuite (see Figure 6).

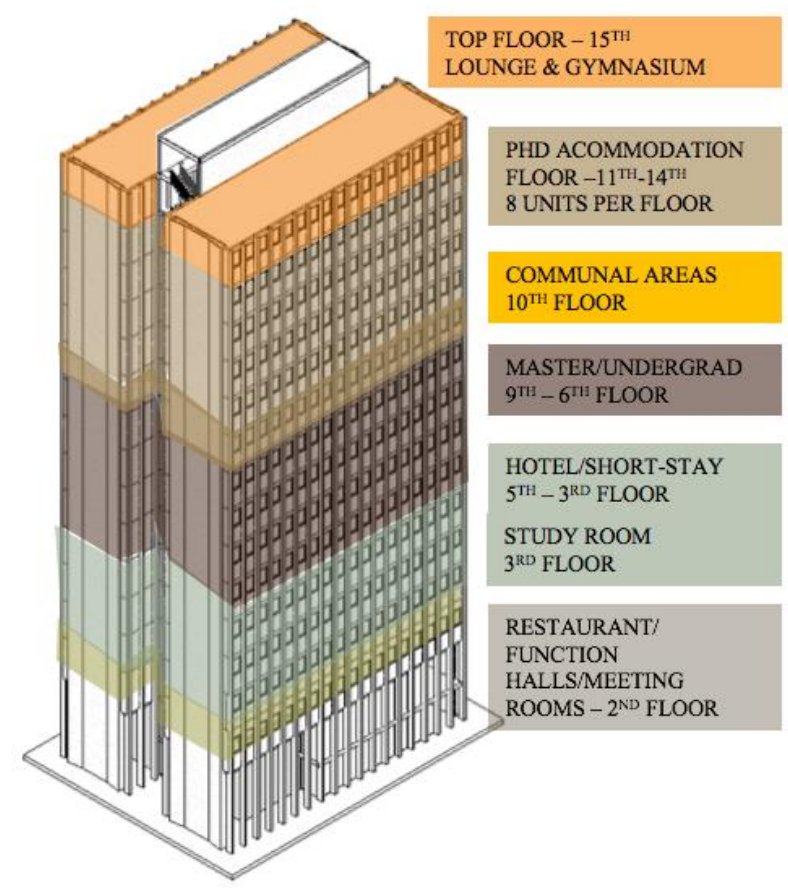

Figure 3. Zones and functions division in the design proposal of the retrofit.

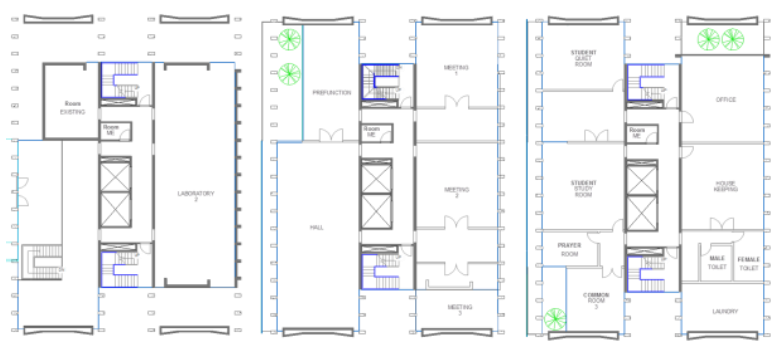

Figure 4. Floor plan proposal for public area.
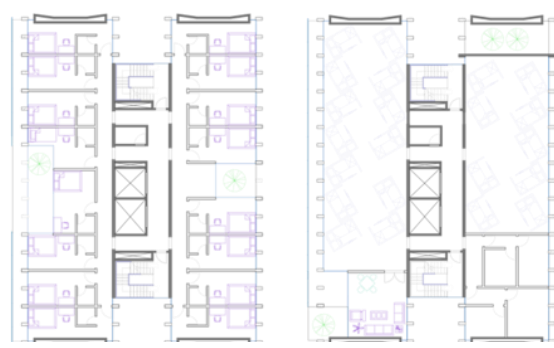

Figure 5. Floor plan proposal for short term accommodation.
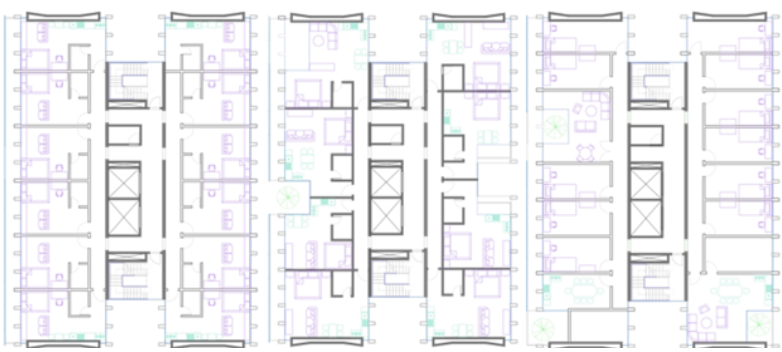

Figure 6. Floor plan proposal for long term accommodation.

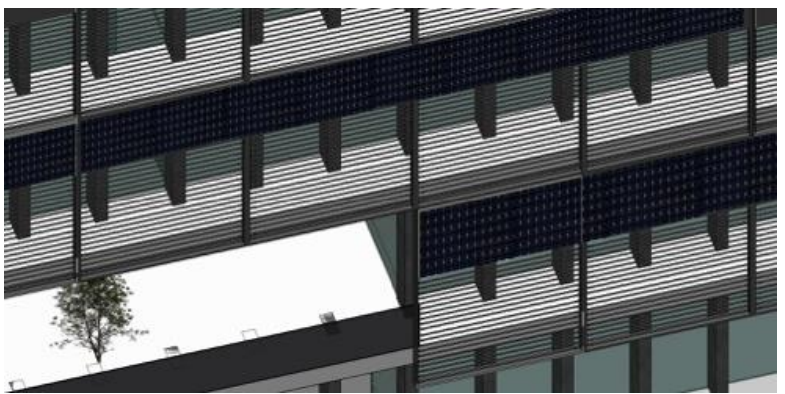

Figure 7. The application of ventilated double skin façade and BIPV system in the southern facade.

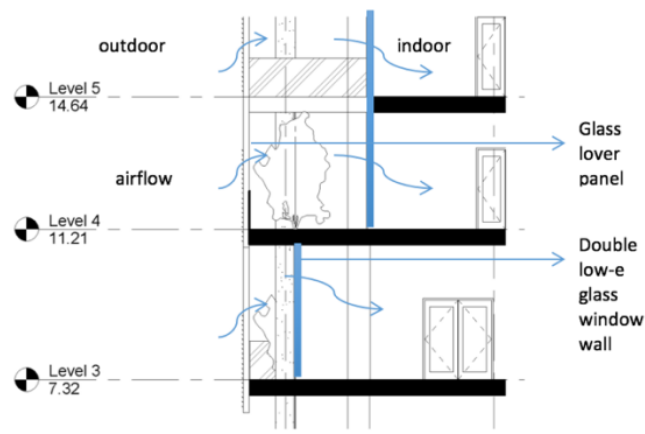

Figure 8. The double skin façade diagram in the building design proposal. 


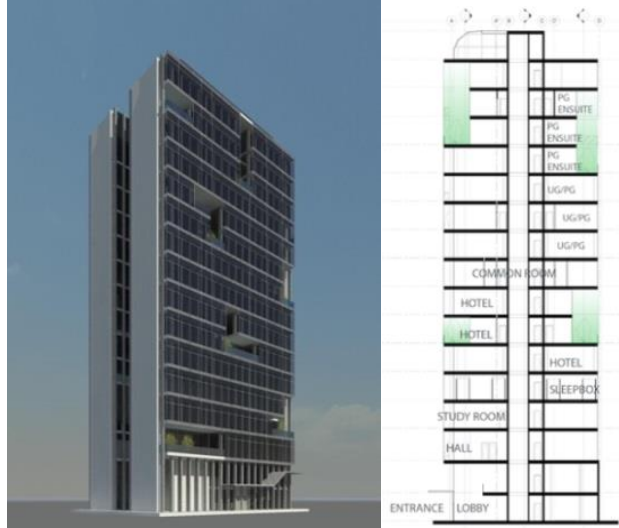

Figure 9. Perspective (left) and building section (right) of Tower Building design proposal.

Figure 7 shows the strategy to configure vertical solar photovoltaic panel in the façade. The idea is that PV panels will be integrated to the building to generate electricity. This is effective to be placed in high-rise building which its side receives high amount of solar radiation. Implementation of façade systems for Tower building is a combination between ventilated double skin façade and BIPV system (see Figure 8). The system is placed in the southern façade, because the maximum solar radiation is coming from this direction.

Figures 9 show that the designed green lung could provide community space and brings natural environment ambient in the tower. The location of the green lung which is near the outer side of building makes it possible to bring natural air from outside flows into interior. The figures also show the idea of integrating double skin façade and green lung in the building at the southern side. In some area, the glass louver panel is open for the green lung and the wall is pushed back 1.5 meters from previous wall position. The holes in double skin façade panel provide natural environment and private balcony for several rooms in the building.

\section{Result and discussion}

From the simulation in the Ecotect, it was revealed that the current Tower Building with office function requires a total of 35.4 MWh energy for heating from October to July (see Figure 10). This number was quite low because the schedule setting for most of the occupants were stayed inside the building only in office hours (8am $5 \mathrm{pm})$. However, with the materials applied in the current building, the energy needed for cooling in the summer time (total 48.2 MWh) was immensely high compared to the heating. The results also show that the highest heat losses were from building fabrics.

On the other hand, when the simulation setting and schedule was changed into accommodation without changing the current building materials, the energy needed for heating was increased significantly with total of $378.5 \mathrm{MWh}$ (see Figure 11). This was already predicted because of the schedule of the operation of accommodation that was almost 24-hours. The highest heat losses were from ventilation because the wall materials might have not enough insulation to prevent the cold weather outside. Meanwhile, as can be seen in the Figure 11, the cooling energy in the summer was lower than the cooling energy for the office function.

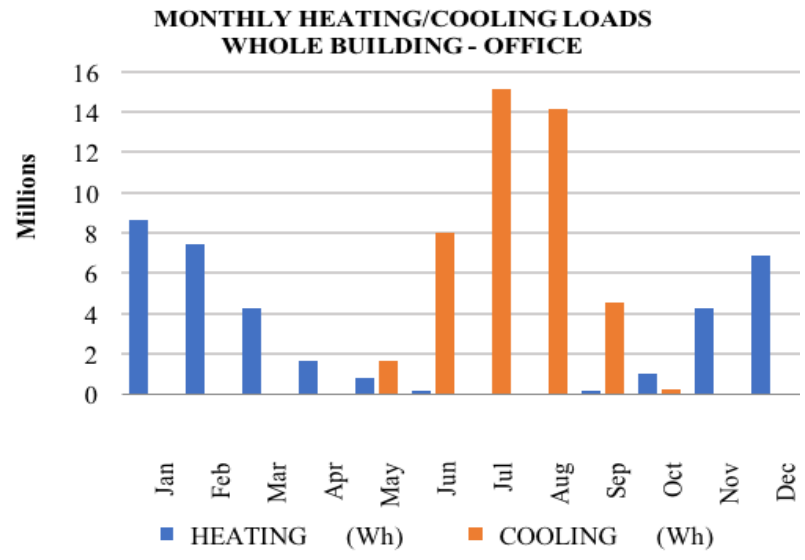

Figure 10. The energy performance of current building as an office.

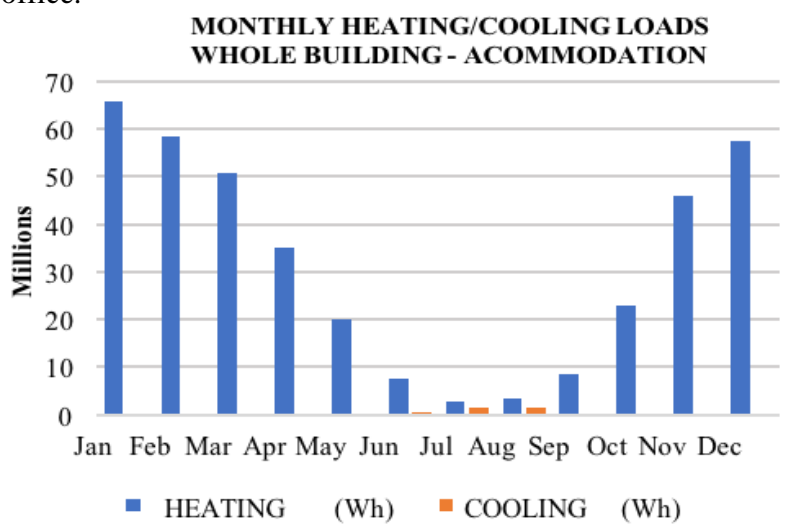

Figure 11. The energy performance of current building as an accommodation.

From the simulation of Tower building before retrofit, the strategies implemented in the project is to improve energy performance to reduce heating and cooling loads especially in the middle floor. For office function, heat gains mostly co me from internal appliances due to occupation. Nevertheless, physical factors of the building also affect the heat gain, such as building fabric and ventilation. This is also the case for accommodation function, except for the percentage of contribution from building fabric and ventilation. For office function, the contribution of heat gain from building fabric and ventilation are $63.80 \%$ and $35.80 \%$ respectively. Whereas, the contribution in the accommodation function are $45.90 \%$ and $53.90 \%$ respectively. Thus, heat gain and losses are improved by changing building fabric and ventilation. A passive solar heating and mixed mode air conditioning also used in the project.

\subsection{Building performance after retrofit}

As described in chapter methodology, after simulating the current building with two different function, several strategies and ideas were installed in the building. The new layouts, materials, and scheduling were then 
simulated again to investigate whether it could reduce the energy demands by enacting current building with accommodation simulation result as a benchmark. It was then affirmed that after retrofit, total heating loads per year is reduced to 207.7 MWh where before retrofit was 378.5 MWh. However, total cooling loads was increased from $4 \mathrm{MWh}$ to $25.5 \mathrm{MWh}$ (see Figure 12).

Figure 13 below shows the integration of BIPV performance in the glass louver panel. The simulation in PVsyst software was done to calculate maximum electricity that could be harvested. With $247.5 \mathrm{~m}^{2}$ total area of vertical PV panels in the Southern façade, the result shows that it could generate $27.7 \mathrm{MWh}$ per year with average $75.87 \mathrm{kWh}$ per day.

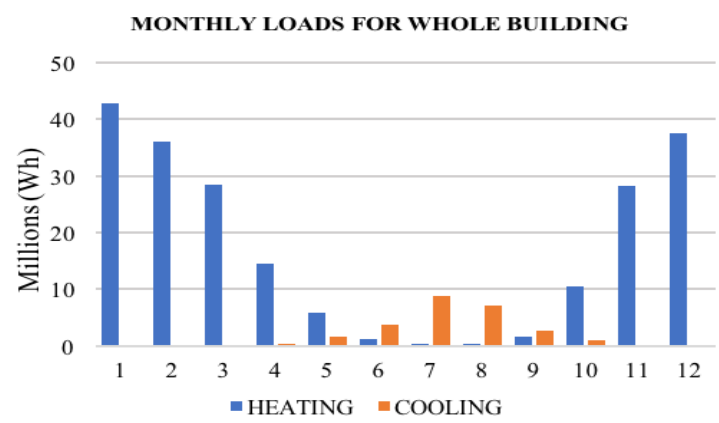

Figure 12. The energy performance after retrofit.

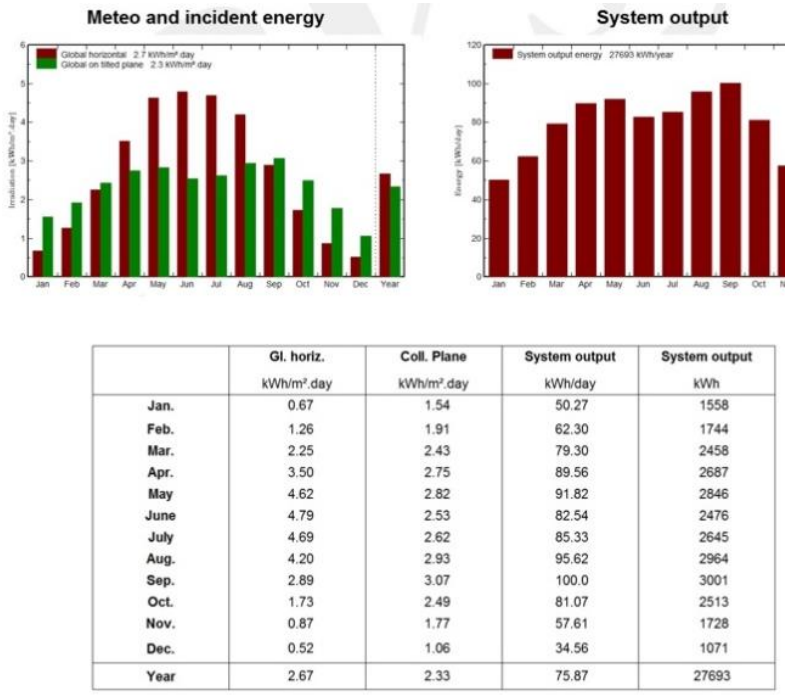

Figure 13. The result of PVsyst simulation to calculate BIPV application.

\section{Conclusions}

Application of sustainable technology in material, passive and active design could enhance performance of the building. Simulations conducted in this project revealed that after retrofit, overall building performance is improved by the strategies applied. However, because of the function change from office to accommodation, energy loads are still high. To replace the energy needed for running the building, sustainable energy harvesting is highly possible. In this detail project, BIPV in façade could generate $3 \%$ or $27.7 \mathrm{MWh}$ annual electricity. If the specification and efficiency of the PV panel was increased, it could generate more than $80 \mathrm{MWh}$ per year. Figure 14 shows how the Tower building will look like from the Clifton boulevard after the retrofit.

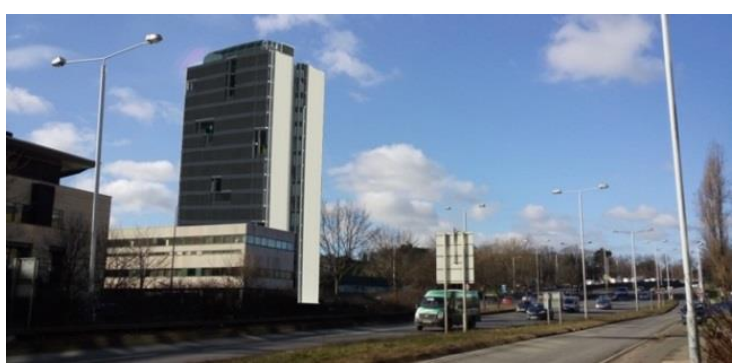

Figure 14. Tower Building after retrofit.

For old buildings in Indonesia with the same case from office to accommodation or vice versa, retrofit could be one alternative solution to reuse the building without demolish it. However, further studies would be needed to show whether the effect of retrofit will be significant.

\section{Acknowledgement}

This building retrofit study was part of the Sustainable Research Project course in the MSc Sustainable Building Technology Program at the University of Nottingham. We gratefully acknowledge the funding from USAID in Sustainable Higher Education Research Alliances (SHERA) program through Centre for Development of Sustainable Region (CDSR).

\section{References}

1. S. Sattary and D. Thorpe, Optimizing embodied energy of building construction through bioclimatic principles, in proceedings of 28th Annual ARCOM Conference, Edinburgh, Association of Researchers in Construction management, pp. 1401-1411 (2012)

2. C. C. Menassa and B. Baer, A framework to assess the role of stakeholders in sustainable building retrofit decisions, Sustain. Cities Soc., 10, pp. 207221 (2014)

3. R. Yang and L. Wang, Multi-objective optimization for decision-making of energy and comfort management in building automation and control, Sustain. Cities Soc., 2, no. 1, pp. 1-7 (2012)

4. S. Burton, Sustainable retrofitting of commercial buildings: cool climates. Routledge (2014)

5. C. C. Menassa, Evaluating sustainable retrofits in existing buildings under uncertainty, Energy Build., 43, no. 12, pp. 3576-3583 (2011)

6. L. Klotz and M. Horman, Counterfactual analysis of sustainable project delivery processes, J. Constr. Eng. Manag., 136, no. 5, pp. 595-605 (2009)

7. E. Asadi, M. G. Da Silva, C. H. Antunes, and L. Dias, Multi-objective optimization for building retrofit strategies: A model and an application, Energy Build., 44, no. 1, pp. 81-87 (2012) 